\title{
20. CHERTS FROM THE EASTERN PACIFIC, LEG 16, DEEP SEA DRILLING PROJECT
}

\author{
G. Ross Heath, School of Oceanography, Oregon State University, Corvallis, Oregon
}

\begin{abstract}
Cherts or porcellanites were encountered at DSDP 157, 158, 162, and 163 of Leg 16. Calcareous sections at DSDP 157, 158, and 163 contain discordant stringers and nodules, whereas clayey and siliceous deposits at DSDP 162 and 163 contain bedded porcellanites. The youngest cherts (late Miocene at DSDP 157) are cristobalite-rich (commonly more than $99 \%$ ). The development of these deposits in pelagic sediments only about six million years old apparently results from high heat flow and rapid sedimentation rates in the area. The oldest cherts (Campanian at DSDP 163). contain roughly equal proportions of quartz and cristobalite, suggesting that the stabler polymorph (quartz) increases with time at the expense of cristobalite. All the cherts appear to have formed from remobilized biogenous opal. There is no evidence of direct volcanic contributions of silica to these deposits.
\end{abstract}

\section{INTRODUCTION}

Chert or porcellanite was sampled at four of the nine sites drilled on Leg 16 (DSDP 157, 158, 162, and 163; Figure 1, Table 1). The geologic youth of DSDP 157 and 158 cherts (Panama Basin) and the thickness and variability of the cherty deposits at DSDP 163 provide insights into the origin of these deposits complementary to those developed by Heath and Moberly (1971), in their study of western Pacific deep-sea cherts. Many of the conclusions discussed here are developments of the earlier paper, which should be consulted for a fuller discussion of the geology and mineralogy of the cherts.

The Leg 16 cherts, like those recovered on most lowlatitude legs of the project, can usually be classified as nodular or bedded. Nodules tend to occur in calcareous sections. In hand specimen they are indistinguishable from flints or nodular cherts found in innumerable exposed limestones on land. Only in thin section do the molds or tests of microfossil plankton reveal the pelagic nature of these deposits.

The bedded cherts, in contrast, are difficult to compare with terrestrial analogues. This reflects in part the uncommon association of lithologies (zeolite-smectite claystones rarely crop out on land) and in part the rarity with which cherts interbedded with poorly consolidated sediments are recovered by the Deep Sea Drilling Project. The bedded cherts or porcellanites resemble portions of the Monterey Formation (Ernst and Calvert, 1969) and similar midTertiary siliceous units bordering the North Pacific. They are also reminiscent of a number of late Mesozoic and Cenozoic bentonites described from the United States

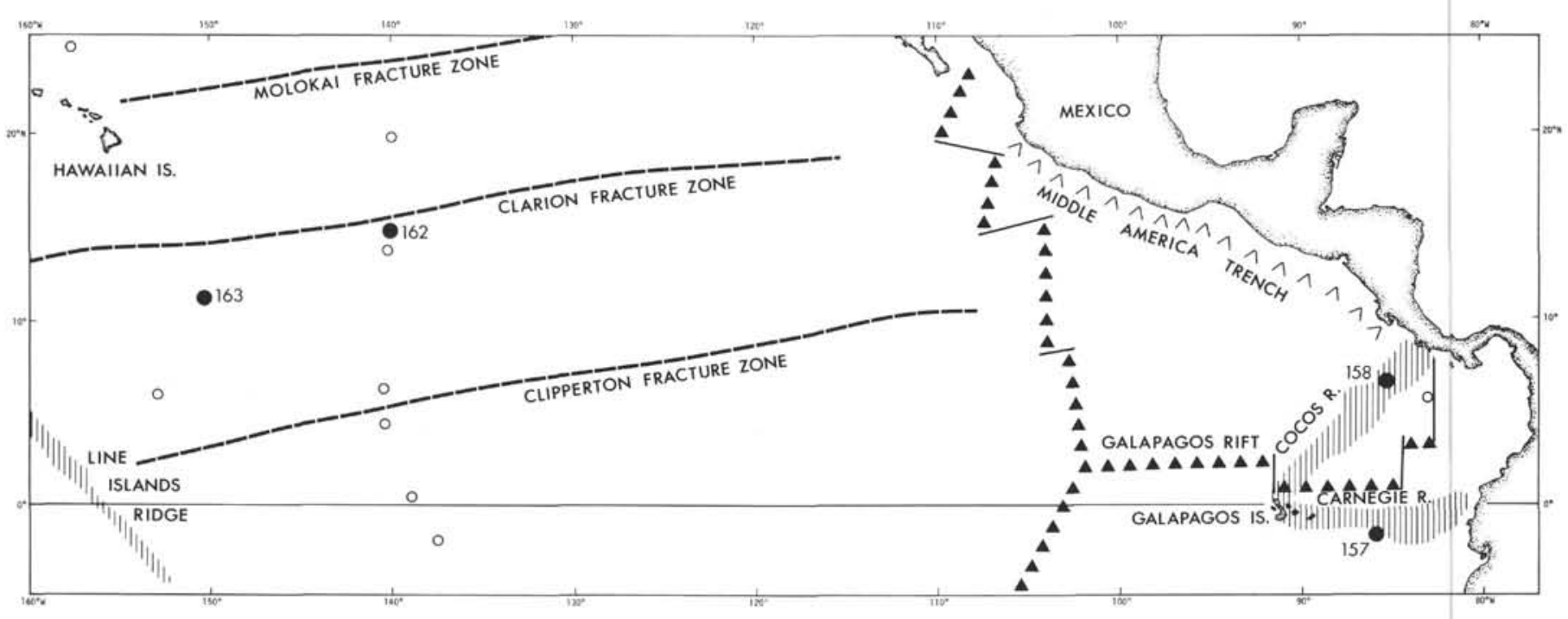

Figure 1. Location of chert-bearing sites (solid circles) drilled on Leg 16 in relation to major structural features of the eastern Pacific. Chert-bearing sites of earlier legs marked by open circles. 
TABLE 1

Cherts and Porcellanites Recovered on Leg 16, Deep Sea Drilling Project

\begin{tabular}{|c|c|}
\hline Sample & Description \\
\hline $157-38-1$ & $\begin{array}{l}\text { Olive brown chert intergrown with nannofossil } \\
\text { chalk. } \\
\text { Age; Late Miocene (Discoaster quinqueramus } \\
\text { Zone). }\end{array}$ \\
\hline $157-38(\mathrm{CC})$ & As $157-38-1$. \\
\hline $157-3$ & $\begin{array}{l}\text { Chert, yellows and olive, intergrown with nanno- } \\
\text { fossil chalk. } \\
\text { Age: Late Miocene (Discoaster quinqueramus } \\
\text { Zone). }\end{array}$ \\
\hline $157-40(\mathrm{CC})$ & As $157-39(\mathrm{CC})$. \\
\hline & $\begin{array}{l}\text { Olive chert intergrown with nannofossil chalk and } \\
\text { limestone. } \\
\text { Age: Late Miocene (Discoaster quinqueramus } \\
\text { Zone). }\end{array}$ \\
\hline $157-41(\mathrm{CC})$ & As $157-41-1$ \\
\hline & $\begin{array}{l}\text { Olive gray chert intergrown with and grading to } \\
\text { siliceous limestone. } \\
\text { Age: Late Miocene (?Discoaster quinqueramus } \\
\text { Zone). }\end{array}$ \\
\hline $157-42(\mathrm{CC})$ & As $157-42-1$ \\
\hline & $\begin{array}{l}\text { Stringers of olive gray nodular chert in nannofossil } \\
\text { chalk limestone. } \\
\text { Age: Late Miocene (?Discoaster quinqueramus } \\
\text { Zone). }\end{array}$ \\
\hline $157-44(\mathrm{CC})$ & $\begin{array}{l}\text { Lenses and veins of olive gray chert in yellowish } \\
\text { gray chalk limestone. } \\
\text { Age: Late Miocene (?Discoaster neohamatus Zone). }\end{array}$ \\
\hline $157-45(\mathrm{CC})$ & $\begin{array}{l}\text { Nodules of olive gray chert with chalk limestone. } \\
\text { Age: Late Miocene (?Discoaster neohamatus Zone). }\end{array}$ \\
\hline $157-46-1$ & $\begin{array}{l}\text { Olive black concretionary chert in greenish gray } \\
\text { chalk limestone. } \\
\text { Age: Late Miocene(?Discoaster neohamatus Zone). }\end{array}$ \\
\hline $157-46(\mathrm{CC})$ & As $157-46-1$. \\
\hline 157 & $\begin{array}{l}\text { Thin nodular chert bodies in gray chalk limestone. } \\
\text { Age: Late Miocene (?Discoaster neohamatus Zone). }\end{array}$ \\
\hline $158-34-1$ & $\begin{array}{l}\text { Olive gray nodular chert with greenish pyritic } \\
\text { nannofossil chalk. } \\
\text { Age: Middle Miocene (Discoaster exilis Zone). }\end{array}$ \\
\hline $158-3$ & 58-34-1. \\
\hline 158 & $\begin{array}{l}\text { Olive black chalcedonic chert with olive gray nanno- } \\
\text { fossil limestone. } \\
\text { Age: Middle Miocene (Discoaster exilis Zone). }\end{array}$ \\
\hline $158-36-1$ & $\begin{array}{l}\text { Yellow green chert with grayish green chalk, over- } \\
\text { lying basalt. } \\
\text { Age: Middle Miocene (Discoaster exilis Zone). }\end{array}$ \\
\hline $162-15-6$ & $\begin{array}{l}\text { Yellow brown porcellanite in clayey radiolarian } \\
\text { nannofossil marl ooze. } \\
\text { Age: Middle Eocene (Nannotetrina quadrata Zone). }\end{array}$ \\
\hline $162-15(\mathrm{CC}$ & $\begin{array}{l}\text { Dark brown porcellanite, conchoidal fracture. } \\
\text { Age: Middle Eocene (Nannotetrina quadrata Zone). }\end{array}$ \\
\hline $162-16-1$ & $\begin{array}{l}\text { As } 162-15(\mathrm{CC}) \text { (? cavings) in clayey radiolarian } \\
\text { ooze. } \\
\text { Age: Middle Eocene (Discoaster sublodoensis } \\
\text { Zone). }\end{array}$ \\
\hline $6-2$ & As $162-16-1$ \\
\hline & As $162-16-1$. \\
\hline $163-5-1$ & $\begin{array}{l}\text { Brown porcellanite beds in radiolarian clay. } \\
\text { Age: Late Eocene (Thyrsocyrtis bromia Zone). }\end{array}$ \\
\hline $163-5-5$ & As $163-5-1$. \\
\hline $163-6-4$ & As $163-5-1$ (cavings). \\
\hline 16 & As 163-5-1 (cavings \\
\hline & $163-5-1$ \\
\hline $163-8-1$ & $\begin{array}{l}\text { Dark brown and light brown laminated porcellanite } \\
\text { with clayey radiolarian ooze. } \\
\text { Age: Middle Eocene (Podocyrtis chalara Zone). }\end{array}$ \\
\hline $163-9-1$ & $\begin{array}{l}\text { Dusky yellowish brown porcellanite with clayey } \\
\text { radiolarian ooze. } \\
\text { Age: Middle Eocene (Podocyrtis mitra Zone). }\end{array}$ \\
\hline
\end{tabular}

TABLE 1 - Continued

\begin{tabular}{|c|c|}
\hline Sample & Description \\
\hline $163-9-3$ & As $163-9-1$. \\
\hline $163-9(\mathrm{CC})$ & As $163-9-1$. \\
\hline $163-10-1$ & As 163-9-1 (cavings). \\
\hline $163-10-5$ & As $163-9-1$ (cavings). \\
\hline $163-11-1$ & As 163-9-1 (cavings). \\
\hline $163-11-6$ & As $163-9-1$ (cavings). \\
\hline $163-12-1$ & As $163-9-1$ (cavings). \\
\hline $163-13(C C)$ & $\begin{array}{l}\text { Dusky yellowish brown, diffusely laminated porcel- } \\
\text { lanite (?cavings). } \\
\text { Age: ? Middle-Early Eocene. }\end{array}$ \\
\hline $163-14-1$ & As $163-13(C C)$ (cavings). \\
\hline $163-14(C C)$ & As $163-13(C C)$ (cavings). \\
\hline $163-15-1$ & As $163-13(\mathrm{CC})$ (cavings). \\
\hline $163-16-1$ & $\begin{array}{l}\text { Dusky yellowish brown to pale orange chert in } \\
\text { nannofossil chalk. } \\
\text { Age: Early Maestrichtian. }\end{array}$ \\
\hline $163-16-2,3,6$ & As $163-16-1$. \\
\hline $163-21-1$ & $\begin{array}{l}\text { Moderate brown nodular chert in nannofossil chalk. } \\
\text { Age: Late Campanian (Tetralithus gothicus trifidus } \\
\text { Zone). }\end{array}$ \\
\hline $163-21-2,4$ & As $163-21-1$ \\
\hline $163-21-5$ & $\begin{array}{l}\text { Yellow brown and moderate orange pink nodular } \\
\text { chert in nannofossil chalk. } \\
\text { Age: Late Campanian (Tetralithus gothicus trifidus } \\
\text { Zone). }\end{array}$ \\
\hline $163-22-1,4$ & As $163-21-5$. \\
\hline $163-23-1$ & $\begin{array}{l}\text { Moderate brown chert in nannofossil chalk. } \\
\text { Age: Campanian (Broinsonia parca Zone). }\end{array}$ \\
\hline $163-24(\mathrm{CC})$ & As $163-23-1$ \\
\hline $163-25-1$ & $\begin{array}{l}\text { Yellowish brown mottled chert in nannofossil chalk. } \\
\text { Age: Campanian (Eiffellithus augustus Zone). }\end{array}$ \\
\hline $163-25(\mathrm{CC})$ & $\begin{array}{l}\text { As 163-25-1 intergrown with silicified nannofossil } \\
\text { limestone. } \\
\text { Age: Campanian (Eiffellithus augustus Zone). }\end{array}$ \\
\hline $163-26-1,2$ & As $163-25(C C)$. \\
\hline $163-27-1$ & $\begin{array}{l}\text { Grayish orange pink and pale brown nodular chert } \\
\text { in nannofossil chalk. } \\
\text { Age: Campanian (Eiffellithus augustus Zone). }\end{array}$ \\
\hline $163-27(C C)$ & As $163-27-1$ \\
\hline $163 \mathrm{~A}-1-1,2$ & $\begin{array}{l}\text { Light brown chert fragments in zeolitic clay. } \\
\text { Age: Early Maestrichtian }\end{array}$ \\
\hline $163 \mathrm{~A}-2(\mathrm{CC})$ & As $163 \mathrm{~A}-1-1$. \\
\hline
\end{tabular}

(see, for example, Reynolds and Anderson, 1967; Reynolds, 1970).

\section{FIELD CHARACTERISTICS}

The Panama Basin cherts (DSDP 157 and 158), which form the flat, strongly reverberant acoustic basement of the Carnegie and Cocos Ridges, all are markedly discordant with respect to the enclosing chalk and marl oozes and indurated carbonates. The chert "blebs" range from a few millimeters to several centimeters in diameter. In general, they are irregular in outline, in extreme cases grading to anastomosing networks of silica with millimeter- to centimeter-sized masses of included limestone. The largest fragments recovered are about $4 \mathrm{~cm}$ in diameter-most are less than $1 \mathrm{~cm}$. Although discordant, many of the chert masses are flattened parallel to bedding. Bioturbation in the enclosing calcareous sediment occasionally persists as subtle mottling in the cherts.

Most of the Panama Basin cherts are olive or black, with conchoidal fracture and sub-vitreous to vitreous 
luster on broken surfaces. Most would be considered flints if exposed on land.

The DSDP 157 and 158 cherts are among the youngest recovered from the deep sea. At DSDP 157, the first chert occurs in the Upper Miocene (Discoaster quinqueramus Zone; about 6 my old). At DSDP 158, the youngest chert was recovered from the Middle Miocene (Discoaster exilis Zone; about 13.5 my old). As discussed later, the youthful age of these cherts probably results from relatively high in situ temperatures due to the thick overburden and high heat flow at these sites (van Andel et al., 1971).

The cherty section cored on the Carnegie Ridge (DSDP 157) is about 90 meters thick compared to less than 20 meters at DSDP 158 on the Cocos Ridge. Whether this difference results from differing degrees of silica mobilization at the two sites or from failure to drill the thickest section on the Cocos Ridge cannot be determined in the absence of seismic reflection data for the sub-chert sediments. The younger age of the DSDP 157 cherts implies greater silica mobility on the Carnegie Ridge.

The Cenozoic cherts from the equatorial sites southeast of Hawaii (DSDP 162 and 163) are similar to cherts previously recovered from sparsely calcareous to noncalcareous sediments in this area (Heath and Moberly, 1971; von der Borch et al., 1971). They are bedded and usually have planar, somewhat gradational boundaries with the adjacent sediment.

These cherts are rarely more than a few centimeters thick. They are in various shades of brown and are porcellanous rather than vitreous, in contrast to the nodular cherts from calcareous sections. Dehydration usually leads to shrinkage and fracturing of the chert fragments. In extreme cases, the rock disintegrates to a mass of 1- to $5-\mathrm{mm}$ chips when exposed to air for a few minutes.

At DSDP 162, the chert marks a lithologic change from clayey radiolarian nannofossil marl through clayey radiolarian ooze to zeolitic brown clay, suggesting some lithologic control of silicification. In contrast, the Cenozoic cherts at DSDP 163 are apparently randomly scattered through more than 60 meters of late and middle Eocene clayey radiolarian ooze. In both cases, the cherts preserve layering and mottling of the original sediment, implying silicification of the sediment rather than displacive growth of chert beds.

The Cretaceous cherts from the basal 100 meters of nannofossil chalk at DSDP 163 do not resemble cherts previously cored in the equatorial Pacific. Their colors (yellows, yellow browns, and orange) and striking preservation of such sedimentary features as burrows set them apart from the nodular cherts described from earlier legs.

In general, the Cretaceous nodules are more equidimensional and simpler in outline than those from the Panama Basin. They commonly have the pale yellow patina that is frequently observed in outcropping cherts. In a few cases, silicification appears to parallel bedding, with all gradations from nannofossil chalk, through porcellanite, to vitreous chert. Unlike the overlying Eocene porcellanites, the Cretaceous nodular cherts fracture conchoidally and do not fragment when dried out.

\section{MINERALOGY AND TEXTURE}

Thin sections of most chert occurrences have been examined to determine the textural relationship of the silica polymorphs to each other and to the host rock. In addition, twenty-two samples were analyzed by X-ray diffraction to provide crude modal analyses of the constituent minerals, most of which are too fine grained for easy optical resolution. All samples were run on a Norelco diffractometer using diffracted-beam monochromatized $\mathrm{CuK} \alpha$ radiation $(35 \mathrm{kV}, 30 \mathrm{~mA})$. The intensity of the diffracted beam was recorded digitally at $2 \theta$ intervals of $0.02^{\circ}$ and, after digital filtering and background removal, was used to estimate the relative abundances of cristobalite and quartz. Comparison of cristobalite-to-quartz ratios estimated by the method of mutual standards (Rex, 1970), and by using an $\alpha$-alumina internal standard in conjunction with experimentally determined reference curves, suggest that the former method (which is much less time consuming) is accurate to within 5 per cent of the measured value at quartz concentrations of 10 per cent or less, and to within 10 per cent (absolute) at higher concentrations.

Like the cherts and porcellanites described previously (Heath and Moberly, 1971), the Leg 16 cherts are mixtures of finely crystallized cristobalite and chalcedonic quartz containing variable amounts of included particulate calcite, clay minerals, zeolites, and iron minerals. The cristobalite corresponds to the "opal-CT" and to a lesser extent the "opal-C" of Jones and Segnit (1971, and references therein); that is, to a basic $\alpha$-cristobalite structure with variable degrees of stacking disorder equivalent to interposed tridymite layers (Flöorke, 1955). In general, the most cristobalitic samples contain the greatest proportion of tridymitic layers, suggesting that inversion to quartz may begin in the tridymite-rich crystallites.

The Panama Basin cherts are all silicified carbonaterich sediments. As described on numerous previous legs, the order of silicification is: (1) infilling of empty chambers of foraminiferal tests, usually with chalcedony; (2) replacement of nannofossil micrite matrix by cristobalite; and (3) replacement (often isomorphic) of the radial calcite crystals of foraminiferal tests by chalcedony. Siliceous microfossils become increasingly rare in the cherty intervals, suggesting that virtually all available biogenous silica has been mobilized to form the chert bodies.

The factors controlling the dissolution of biogenous opal and nucleation of cristobalitic chert are still obscure, although the free energy change involved in the marked increase in crystallite size accompanying the process may help drive the conversion. The molecular scale of the process is evident from the preservation of fine details of sedimentary structure in the chert nodules and by the pseudomorphing of calcite crystals mentioned previously. Local pseudomorphing of radiolarian tests by pyrite in the cherty intervals shows that diagenetic activity is not restricted to the silica minerals.

The extremely rare occurrence of radiolarian tests inverted to cristobalite in the sediment adjacent to chert nodules suggests that a solution step may not be essential for the inversion of opal to cristobalite. The absence of 
identifiable structures in the opal, however, makes the distinction of in situ inversion from pseudomorphing almost impossible.

The Panama Basin cherts are all cristobalite-rich. Nine of twelve samples X-rayed contain more cristobalite than quartz. The range of cristobalite-to-quartz ratios spans almost four orders of magnitude (0.09 to 450$)$, and the range (0.09 to 280$)$ at DSDP 157 alone exceeds that for all Leg 7 sites (Heath and Moberly, 1971).

The Cenozoic cherts at DSDP 162 and the upper part of DSDP 163 are very similar to the porcellanites of the same age from Sites DSDP 65 and 66 of Leg 7, some 3000 $\mathrm{km}$ to the southwest. Cristobalite-to-quartz ratios exceed $10: 1$ and commonly are close to $100: 1$. Under the microscope, these rocks are almost featureless, with an overall "mudcracked" structure of $2-3 \mu$ cristobalite units. In a few cases, "ghosts" of radiolarian tests are visible as clearer patches in a somewhat clayey matrix. In other cases, careful examination of apparently structureless porcellanite under plane polarized light, with the condenser iris diaphragm stopped down as far as possible to accentuate subtle variations in relief, reveals the outlines of a close-packed mass of radiolarian tests.

These bedded cherts or porcellanites are the most controversial of all the deep-sea cherts. Their mineralogical similarity (smectite-zeolite-"opal-CT") to altered volcanic debris on land (Reynolds and Anderson, 1967; Reynolds, 1970) suggests a similar origin; that is, remobilization of silica in a series of volcanic ash beds. The author believes, however, that the absence of pseudomorphs or molds of glass shards and the occasional occurrence of recognizable silicified siliceous ooze that is mineralogically and macroscopically indistinguishable from the featureless bedded porcellanites are strong evidence that the silica is of biogenous origin. Certainly, the mass of silica represented by these deposits would not produce any detectable imbalance in the present budget of dissolved silica in the oceans (Heath, in press).

Under the microscope, the Cretaceous cherts from the basal portion of DSDP 163 resemble the Panama Basin occurrences but are richer in quartz (the weight ratio of cristobalite to quartz is close to 1 ). Generally, the centers of the nodules consist of a mosaic of fine $(2-5 \mu)$ crystals of chalcedonic quartz with irregular included patches rich in cristobalite. "Ghosts" of radiolarian tests and, less commonly, foraminifera are found in most nodules.

The nodules are rimmed by a patina of cristobalite 0.1 to $1 \mathrm{~mm}$ thick. Apart from a few molds and pseudomorphs of foraminifera and radiolarians, the patinas are very uniform and rather featureless masses of submicroscopic crystallites. The contact between patina and enclosing marl is generally sharp but may be irregular. The cristobalite-chalcedony boundary is more gradational but is usually fairly simple.

The surrounding marl contains few recognizable microfossils. Circular and lenticular masses of chalcedony probably represent replaced radiolarian tests; however, morphological details can rarely be identified. Tests replaced by cristobalite usually retain more ornamentation than those replaced by chalcedony. Foraminifera (filled with chalcedony) are rare.

\section{DISCUSSION AND CONCLUSIONS}

The cherts and porcellanites recovered on Leg 16 reinforce conclusions of previous studies and perhaps help resolve the ultimate origin of the silica in these rocks. General conclusions are:

1. The cherts and porcellanites are formed by the diagenetic remobilization of biogenic opal, principally the the frustules of diatoms and the tests of radiolarians.

2. Volcanic contributions of silica to cherts can never be totally discounted. Nevertheless, the close association of cherts with opal-bearing sediments, the absence of recognizable volcanic debris in most cherts, and knowledge of the geochemistry of silica in the sedimentary cycle today all oppose the necessity for an exotic source of mobile silica.

3. In all cases, the cherts contain the silica polymorphs cristobalite ("opal-CT" of Jones and Segnit, 1971) and quartz. Dissolution of opaline tests, migration of dissolved silica over maximum distances of the order of 1 meter, and formation of cristobalite layers or nodules by replacement of calcareous sediments or impregnation of clays or siliceous oozes seems to be the primary mode of chert formation.

4. Siliceous microfossils are rarely preserved in cherty beds. Mechanisms responsible for the occasional conversion of opaline tests to cristobalite or chalcedony without loss of ornamental details are not understood.

5. Cherts in calcareous sediments tend to be nodular, whereas those in siliceous oozes or clays are bedded. In both cases, preservation of original sedimentary structures, particularly fine laminae, indicate that the sediments were quite compact when silicification began and suffered little distortion during the process.

6. Factors controlling the diagenetic mobilization and deposition of silica are not understood. In the absence of experimental data, it is doubtful whether existing or future field observations are capable of resolving the problem. Leg 16 results, together with data from earlier legs, imply that for cherts to form in sediments deposited since about the middle Oligocene ( $\sim 30$ my ago), very high in situ temperatures are necessary. The exact values are still uncertain, but are probably close to $30^{\circ} \mathrm{C}$ for the youngest cherts. Such high temperatures require one or more of the following: (a) high heat flow; (b) steep thermal gradient in the overlying sediments (low thermal conductivity); or (c) a thick layer of overlying sediments. In the Panama Basin, DSDP 157 and 158 are both in areas of high heat flow $\left(\sim 3 \mu \mathrm{cal} / \mathrm{cm}^{2} \mathrm{sec}\right)$ and have sedimentation rates that are high for pelagic areas.

As is clear from drilling results in the Atlantic, a high in situ temperature may be a necessary condition for the formation of young cherts, but is certainly not sufficient alone. Apparently a critical concentration of biogenous opal in the sediment is also necessary.

7. Once cristobalite cherts have formed, inversion to quartz can proceed by the Ernst and Calvert (1969) mechanism. If so, the cristobalite-to-quartz ratio in a chert should reflect only the integrated effect of the in situ temperature during the life span of the chert. 


\section{ACKNOWLEDGMENTS}

I am grateful to other members of the Leg 16 scientific staff for stimulating discussions on the "chert problem." Sincere thanks are also due to T.C. Moore, Jr., for continued advice and criticism of this work.

\section{REFERENCES}

Ernst, W.G. and Calvert, S.E., 1969. An experimental study of the recrystallization of porcelanite and its bearing on the origin of some bedded cherts. Am. J. Sci. 267-A, 114.

Floorke, O.W., 1955. Zur Frage des "Hoch"-Cristobalit in Opalen, Bentoniten and Gläösern. Neues Jahrb. Mineral, Monatsh. 10, 217.

Heath, G.R., in press. Dissolved silica and deep-sea sediments. In Studies in Paleo-Oceanography. Soc. Econ. Paleontologists Mineralogists Spec. Publ. W.W. Hay (Ed.).

Heath, G.R. and Moberly, R., Jr., 1971. Cherts from the western Pacific, Leg 7, Deep Sea Drilling Project. In Winterer, E.L., Riedel, W.R. et al., 1971. Initial Reports of the Deep Sea Drilling Project, Volume VII. Washington, (U.S. Government Printing Office). 991.
Jones, J.B. and Segnit, E.R., 1971. The nature of opal. I. Nomenclature and constituent phases. J. Geol. Soc. Australia. 18 (1), 57.

Reynolds, R.C., Jr. and Anderson, D.M., 1967. Cristobalite and clinoptilolite in bentonite beds of the Colville Group, northern Alaska. J. Sediment. Petrol. 37 (3), 966.

Reynolds, W.R., 1970. Mineralogy and stratigraphy of lower Tertiary clays and claystones of Alabama. J. Sediment Petrol. 40 (3), 829.

Rex, R.W., 1970. Shore-based laboratory procedures (X-ray mineralogy). In Bader, R.G., Gerard, R.D. et al., 1970. Initial Reports of the Deep Sea Drilling Project, Volume IV. Washington (U.S. Government Printing Office). 748.

van Andel, Tj. H., Heath, G.R., Malfait, B.T., Heinrichs, D.F. and Ewing, J.L., 1971. Tectonics of the Panama Basin, eastern equatorial Pacific. Bull. Geol. Soc. Am. 82 (6), 1489

von der Borch, C.C., Galehouse, J. and Nesteroff, W.D., 1971. Silicified limestone-chert sequences cored during Leg 8 of the Deep Sea Drilling Project: a petrologic study. In Tracey, J.L., Jr., Sutton, G.H. et al., 1971. Initial Reports of the Deep Sea Drilling Project, Volume VIII. Washington (U.S. Government Printing Office). 819. 